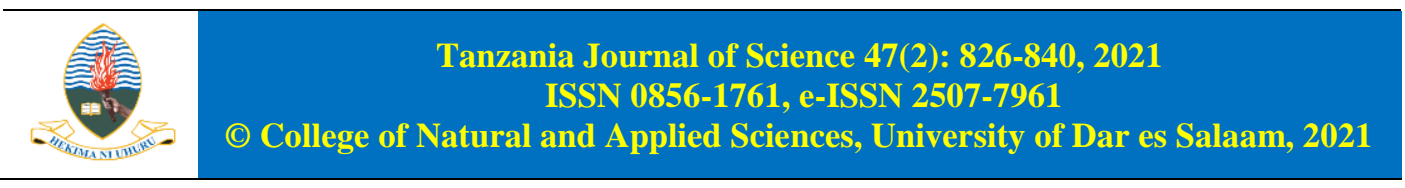

\title{
Probabilistic Seismic Hazard Assessment and Site Analyses of Arusha International Conference Centre (AICC), Arusha, Tanzania
}

\author{
Richard W Ferdinand \\ Department of Geosciences, University of Dar es Salaam, Dar es Salaam, Tanzania. \\ E-mail: rfwambura@gmail.com
}

Received 21 Mar 2021, Revised 21 May 2021, Accepted 28 May 2021, Published May 2021

DOI: https://dx.doi.org/10.4314/tjs.v47i2.37

\begin{abstract}
This work presents the evaluation of earthquake resistance of the Arusha International Conference Centre (AICC) complex, in Tanzania. The evaluation included probabilistic seismic hazard analysis (PSHA) and site response analysis. Seismic sources considered to constitute a seismic hazard in this study were randomly occurring seismicity located within five tectonic provinces around the site. For each province the seismic hazard is based on a cursory analysis of earthquake data from compiled ESARSWG bulletins and temporary deployed networks within the North Tanzania Divergence (NTD). Bedrock response signal together with the information of material characteristics from boreholes around the AICC site were used in analysis of site response. PSHA results indicated uniform hazard spectra values of $0.15,0.2$ and $0.27 \mathrm{~g}$ for return periods of 475 , 975 and 2475 years, respectively. The surface ground response results indicated a maximum amplification factor of 3.7 and a spectral response of $4.5 \mathrm{~g}$ for a wave period of $0.6 \mathrm{sec}$ that matches the natural frequency of the 6-7 storey buildings of the AICC complex. It is this resonance effect on the buildings that is assumed to have caused intense shaking in the earthquake of December $5^{\text {th }} 2005$ from Lake Tanganyika.
\end{abstract}

Keywords: Probabilistic seismic hazard analysis, Arusha International Conference Centre, East African Rift System, Uniform hazard spectra, Site effect.

\section{Introduction}

On December $5^{\text {th }} 2005$, the Arusha International Conference Centre (AICC) buildings in Arusha City, Tanzania were shaken by propagation of seismic waves around the site. The Centre is located along the eastern branch of the East African Rift System (EARS) and is the place that hosted the International Criminal Tribunal for Rwanda (ICTR). The earthquake caused a panic attack to its inhabitants who desperately struggled to get out of the buildings. It also caused some minor damages to the buildings. However, a quick assessment across the neighbourhood of the site indicated that short structures of 1-2 storey buildings were not affected. Later on, it was learnt that the propagating waves that shook the buildings were generated by a magnitude, Mw, 6.8 earthquake in Lake Tanganyika area about $700 \mathrm{~km}$ away from the AICC site. This remoteness of the source prompted an investigation to find out why the AICC building structures responded strongly to the propagating waves and what will be the seismic hazard levels at the site in case a moderate to large earthquake occurs close by.

When assessing seismic hazard for the site, it is considered that local geologic conditions at a specific site have influence upon the characteristics of earthquake strong ground motion (Chávez-García et al. 1996). Usually, younger and softer soils amplify ground 
motion more strongly than older and more consolidated soils or bedrock. The first order effects related to near-surface properties and geometry of thick soil sites are impedance contrast amplification and resonance amplification (Shearer and Orcutt 1987). In addition, localized, large surface amplifications are possible to occur due to focusing of body waves by topography on the buried bedrock surface (Frankel and Vidale 1992). Surface topography can also influence the interaction of seismic waves producing complex patterns of amplification and deamplification. Thus knowledge of the elastic parameters of the overburden-rock system and the geometry of the basement are essential to both understand and estimate these amplification effects.

Studies of destructive earthquakes of Mexico City in 1985, Northridge in 1994, Kobe in 1995, Colombia in 1999, Turkey in 1999 and Haiti in 2010 have shown that during earthquakes, damages are often caused by amplification of ground shaking at certain frequencies in near-surface geology, whilst the post-disaster damage assessment showed that the local site effects have a dominant contribution on the intensity of damage and destruction (Lacave et al. 1999, Pitilakis 2004, Atakan et al. 2002, DesRoches et al. 2011). In Tanzania, the recent Kagera earthquake (Mw 5.9) of 2016 has revealed the impact of site effects as key player in damage distribution. Moreover, the sediment-induced amplification and ray focusing within the strong topographic relief are most likely phenomena to explain the macroseismic observations (Ferdinand et al. 2017, Mulibo 2019). Following the impact of Kagera earthquake (Ferdinand et al. 2017), the Government of Tanzania decided to adapt seismic hazard assessment as part of investigative measures apart from geotechnical for Government construction projects in areas of high seismicity. Examples of Government projects that have involved PSHA are the construction of Football stadium in Dodoma City (Ferdinand et al. 2018), the government plots for administrative city of Dodoma (Ferdinand et al. 2020), and residential plots for housing the department of Fire and Rescue Force in Dodoma (Ferdinand et al. 2021).

This recent work aimed to account for the causes of strong ground response to earthquakes at the AICC site and the potential seismic hazards if moderate or large earthquakes occur close to the site. An example of a moderate event close by the site is the earthquake of July 2007 Lake Natron (Mw 5.9) that occurred about $70 \mathrm{~km}$ away from the AICC site which also shook the AICC buildings (Calais et al. 2008). The analysis of AICC site response drew from a stock of relevant literature and analysis of seismic data from bulletins of the East and Southern Africa Regional Seismology Working Group (ESARSWG) and catalogues of the temporary networks within Tanzania. To achieve the final objective, i.e., the seismic hazard levels of the AICC complex site, two sets of results were important. Uniform hazard spectra (UHS), defined as bedrock acceleration response spectra where each ordinate has a predefined annual frequency of exceedance are presented for three return periods; 475, 975 and 2475 years. The second set of results consists of the surface response spectra (surface ground motion) at the AICC site.

\section{Tectonic and Geologic Setting The tectonic setting}

The City of Arusha is located within the Northern Tanzania divergence zone (NTD) along the Eastern branch of the East African rift system (EARS). The Cenozoic EARS constitutes the longest example of a continental narrow rift, running for $\sim 3000 \mathrm{~km}$ from Afar triple junction in Ethiopia to the Zambezi valley in southern Mozambique (Nyblade and Robinson 1994, Chorowicz 2005, Ring 2014). Along its course, the EARS includes three well defined rift segments, namely the Main Ethiopian rift (MER), the Western branch (WB) and the Eastern branch (EB) (Nyblade and Robinson 1994, Chorowicz 2005, Ring 2014).

The Eastern branch is tectonically divided into northern (Kenyan rift) and southern parts 
(Tanzanian segment) with assumed region of separation along the E-W line of volcanic centre of Northern Tanzania (Fairhead and Stuart 1982). The Tanzania segment has developed in Archean lithosphere in the west (Eyasi-Wembere rift) and in Late Proterozoic
(Pan-Africa) Orogenic belts along its central (Manyara-Balangida rift) and the eastern limb (Pangani rift) (Foster et al. 1997). Based on this division, the northern Tanzania section is referred to as the North Tanzania Divergence (NTD) (Figure 1).

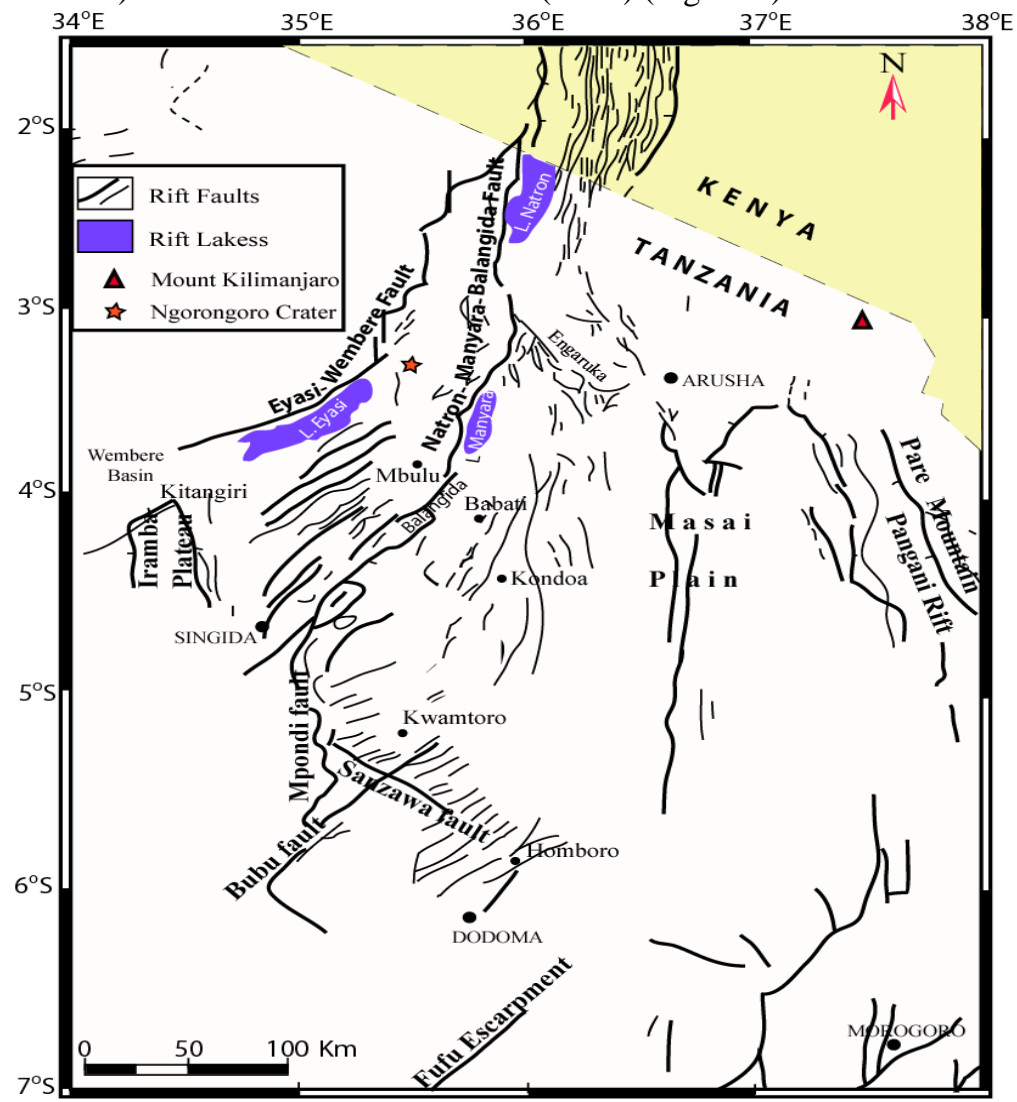

Figure 1: The North Tanzania Divergence showing the position of the three rift arms; EyasiWembere Rift, Manyara-Balangida Rift and Pangani Rift (Modified after Daudi 2007).

In the NTD, the three rift arms are arranged within a nearly $300 \mathrm{~km}$ wide zone of deformation. Their basement deformation history is relatively well established (McConnell 1972), as well as the deep structure of the western and central rift arms (Ebinger et al. 1997). The Pangani rift arm extends over $200 \mathrm{~km}$ at NNW- SSE, immediately south of the Kilimanjaro volcano. It comprises 3 main discrete blocks, separated by transverse depressed zones and increasing topographic elevation southwards from $1600 \mathrm{~m}$ in the North Pare Mountains to $2100 \mathrm{~m}$ in the Usambara Mountains (Le Gall et al. 2008, Albaric et al. 2010). The elongated high zone corresponds to an asymmetric faulted block. The Pangani arm is considered to be less active as compared to the other two arms (Girdler 1991, Ebinger et al. 1997). Along Pangani, volcanism is restricted to Late Pliocene to recent (Foster et al. 1997, Nonnotte et al. 2008).

The Manyara-Balangida rift is composed of Manyara fault and Balangida fault. The $120 \mathrm{~km}$ 
long Manyara fault trends NNE-SSW, while the Balangida fault trends NE-SW. The present day Manyara escarpment formed after a major phase of volcanic eruption at $\sim 1.2 \mathrm{Ma}$ (Foster et al. 1997, Le Gall et al. 2008). Volcanism within Balangida began in Pliocene time (Foster et al. 1997, Le Gall et al. 2008). The Eyasi arm can be traced through the nearly linear extended Eyasi fault. The NE-SW trending fault is more than $90 \mathrm{~km}$ long. The uplifted block is composed of Archean basement rocks.

In looking at the seismicity, the NTD shows high seismic activity that spread out over a much wide area (Albaric et al. 2009, Msabi 2016) with Manyara and Eyasi faults dominating. The largest recorded earthquake occurred along this area on May $7^{\text {th }} 1964$, with a magnitude 6.4 (Iranga 1991). Accurate earthquake depth determination from waveform analysis (Brazier et al. 2005, Mulibo and Nyblade 2009), together with a microearthquake survey (Nyblade et al. 1996) revealed the seismogenic thickness down to 35 $\mathrm{km}$. Such depth could suggest a thick and strong crust that can accommodate brittle failure.

The distribution of the fault plane solutions shows that within the NTD, the focal mechanisms are predominantly normal with few strike slip faults (Brazier et al. 2005, Mulibo and Nyblade 2009). The extension direction in the Manyara arm is WNW-ESE consistent to the general trend of the EARS (Daudi 2007). The extension direction changes as the rift encounters the Tanzanian Craton to the south of Manyara (Daudi 2007, Albaric et al. 2010). Based on the direction of the tensional stresses deduced from fault plane solution, Daudi (2007) grouped the ManyaraBalangida and Eyasi arms into three earthquake source zones, i.e., the Manyara, the Eyasi and Kondoa zones (Figure 3).

\section{The Geological Settings}

The geological background to the NTD is schematically shown in Figure 2. The area encompasses different rock types that range from Neoarchean (about $3.0 \mathrm{Ga}$ ) to Recent (e.g., active carbonatite volcano of Oldoinyo Lengai in northern part). It is mainly covered by rocks of the Dodoman Supergroup in the south-west and that of the Palaeo-Proterozoic Mozambique belt in the eastern part separating the Tanzania Craton to the west. Nyanzian rocks occur in patches which cover the western part within the Tanzania Craton whereby Kavirondian rocks and Bukoban sediments characterize the north-western part (Quennell et al. 1956, Cahen et al. 1984, Schlüter 1997, Manya 2005). The northern part is largely covered by volcanic rocks of Tertiary age (4.8 Ma) to Recent. During rifting episodes in Tertiary times, half graben structures were formed along the EARS and were filled with continental sediments (Schlüter 1997, Foster et al. 1997, Le Gall et al. 2008, Nonnotte et al. 2008).

\section{Geological overview of Arusha}

The Arusha City is entirely covered by Tertiary volcanic rocks that belong to the Kilimanjaro volcanic province (Schlüter 1997, Foster et al. 1997, Nonnotte et al. 2008). The volcanic rocks include the basalt of different textures, i.e., vesicular basalt or scorecious basalts and massive basalt. It also includes pyroclastic rocks, i.e., tuff, lapilli tuff, aggromerates and volcanic breccia. The volcanic rocks vary in thickness from several meters to several hundreds of meters (Mwangimba 1992). The volcanic rocks usually overlying unconformably the Precambrian metamorphic basement belonging to the Palaeo-Proterozoic Mozambique belt, mainly gneisses and schists. 


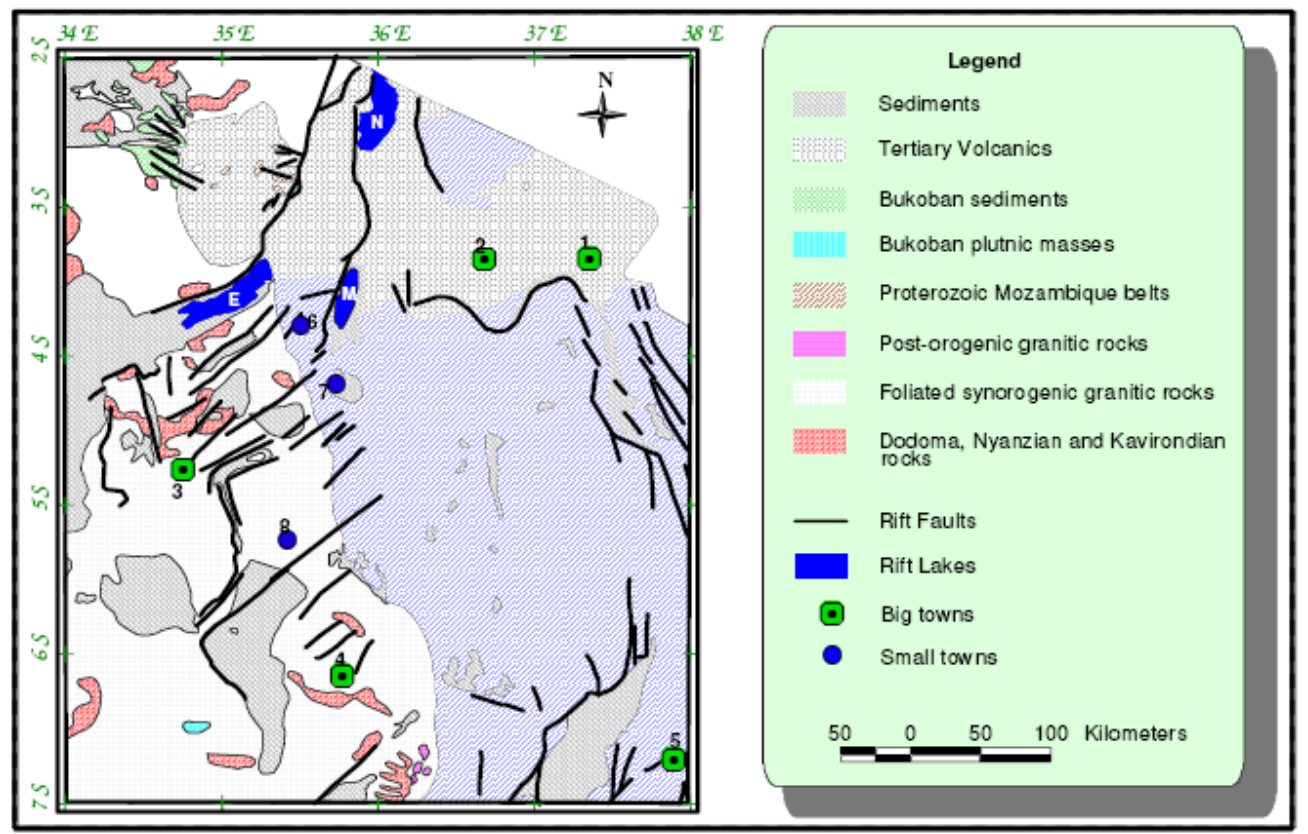

Figure 2: The Northern Tanzanian Divergence showing geological outline (modified after Daudi 2007).

The drill hole at the AICC complex revealed the following sequence of rocks types (DDCA 2001): The top dark clay soil of about $2 \mathrm{~m}$ thick underlain by the volcanic lapilli tuff intercalated with tuff or volcanic ash to a depth of $40 \mathrm{~m}$. Below $40 \mathrm{~m}$ deep, lapilli tuff and volcanic ash are underlined by volcanic tuff and aggromerate up to $50 \mathrm{~m}$ thick. From around a depth of $52 \mathrm{~m}$ to $78 \mathrm{~m}$ volcanic tuff and volcanic breccia dominate. The volcanic tuff and aggromerates dominate from 78 to 98 $\mathrm{m}$ thick. The rock sequence across a depth of $100 \mathrm{~m}$ changes from volcanic tuff through lapilli tuff to solid basalt rock. Different layers of volcanic rocks in the observed sequence depict different phases of volcanic eruptions.

Around the Arusha City, drilled boreholes at different places reveal similar results. For example, at Mianzini, the top black clay soil, a typical weathering product of basalt volcanic rocks extended to a depth of $4 \mathrm{~m}$ underlain by coarse angular gravel basaltic material (basaltic volcanic breccia) that passes through volcanic tuff and ashes ashes (Mwangimba 1992,
DDCA 2001, 2002, 2003, 2004, 2005). Rock sequence alternates with agglomerate (rounded to subrounded pyroclastics) and volcanic tuff/ashes and lapilli tuff, up to a depth of 196 $\mathrm{m}$. Within the observed sequence, basalt is partly weathered at depth due to physical and chemical impacts of groundwater. Solid basalt is however encountered at a depth of more than $200 \mathrm{~m}$.

Generally, the geological settings of Arusha city are covered by the volcanic rocks ranging from basalt lava to pyroclastic rocks both acidic and basic in composition with the source as Mount Meru and its cinder cones "parasitic cones". The volcanic rocks occur in layers of different thicknesses depending upon the conditions of volcanic eruption. The thickness of volcanic pile decreases away from the slopes of Mount Meru towards the Precambrian metamorphic basement (gneisses, quartzite and graphitic schist). The basement can be traced a few km from the Kilimanjaro Airport towards Melerani in Simanjiro District to the east, 
towards Babati in Manyara region to the south and towards Longido in Longido District.

\section{Methods \\ Probabilistic Seismic Hazard Analysis (PSHA)}

The goal of PSHA is to estimate the probable distribution of future ground motions at specified levels of earthquake exposures. PSHA integrates a computation of hazards from all significant seismic sources, incorporating the annual frequencies of ground motion occurrence from each seismic source, to obtain an estimate of total hazard, defined as the mean annual rate at which a given acceleration will exceed some specified threshold at a prescribed site (Cornell 1968, McGuire 1976). The PSHA approach requires a seismic source zonation, characterization of each zone and a regional modelling for the seismic wave attenuation, which is also called the ground motion prediction equation (GMPE).

\section{Seismic sources}

Although it is known that earthquakes are generally caused by fault movements, the fault systems in the area surrounding the AICC site were not precisely documented, and therefore it was not possible to identify specific earthquake-generating fault with certainty. Consequently, this work endeavoured to delineate seismotectonic source areas, i.e., seismotectonic provinces of the study site. The criteria for division of the provinces around the site were based on observed seismicity, trends of the faulting and stress patterns within the area (Daudi 2007, Msabi 2016). Based on these criteria, five tectonic provinces (source zones) in the neighbourhood of AICC complex site were established, namely; Natron-Magadi, Manyara, Lake Eyasi, Kondoa and Pare
(Figure 3). The seismicity in each source zone was treated as local and randomly occurring earthquakes within the same seismogenic zone.

Earthquake data from the Tanzanian catalogue extends back to 1846 . However, the catalogue lacks completeness and homogeneity as most of the contributing seismic stations in the past were based from the northern hemisphere (Iranga 1991). Following the deployment of seismic stations in Tanzania and the establishment of the collaboration among the nine countries along the East African rift system, the two mentioned problems were addressed. Thus, in this work the earthquake data from bulletins of the ESARSWG (19921998) and additional data from a one year (1994-1995) IRIS temporary experiment (Nyblade et al. 1996) were used to generate seismic source zones distribution around the AICC site.

Analysis of the data from all the five source zones indicated a uniform distribution of earthquakes within the seismogenic zone down to a depth of $35 \mathrm{~km}$ (Nyblade et al. 1996, Daudi 2007). Based on a documentation of seven years data, the study identified recurrence relations for only three zones as there was no enough data to study the other two zones. Table 1 summarizes the recurrence relations for the three zones and for the whole region that combines all the five zones together. It was noted that recurrence relation results for Manyara, Natron-Magadi and Pare are similar and compared well with results from combined zones. Based on these results, it was found that an event of magnitude 5.0 would occur every year, magnitude 6.3 in every 10 year and magnitude 7.5 in 100 years. This observation is supported by the presence of a magnitude 6.4 between Manyara and Eyasi (Bath 1975, Iranga 1991). 


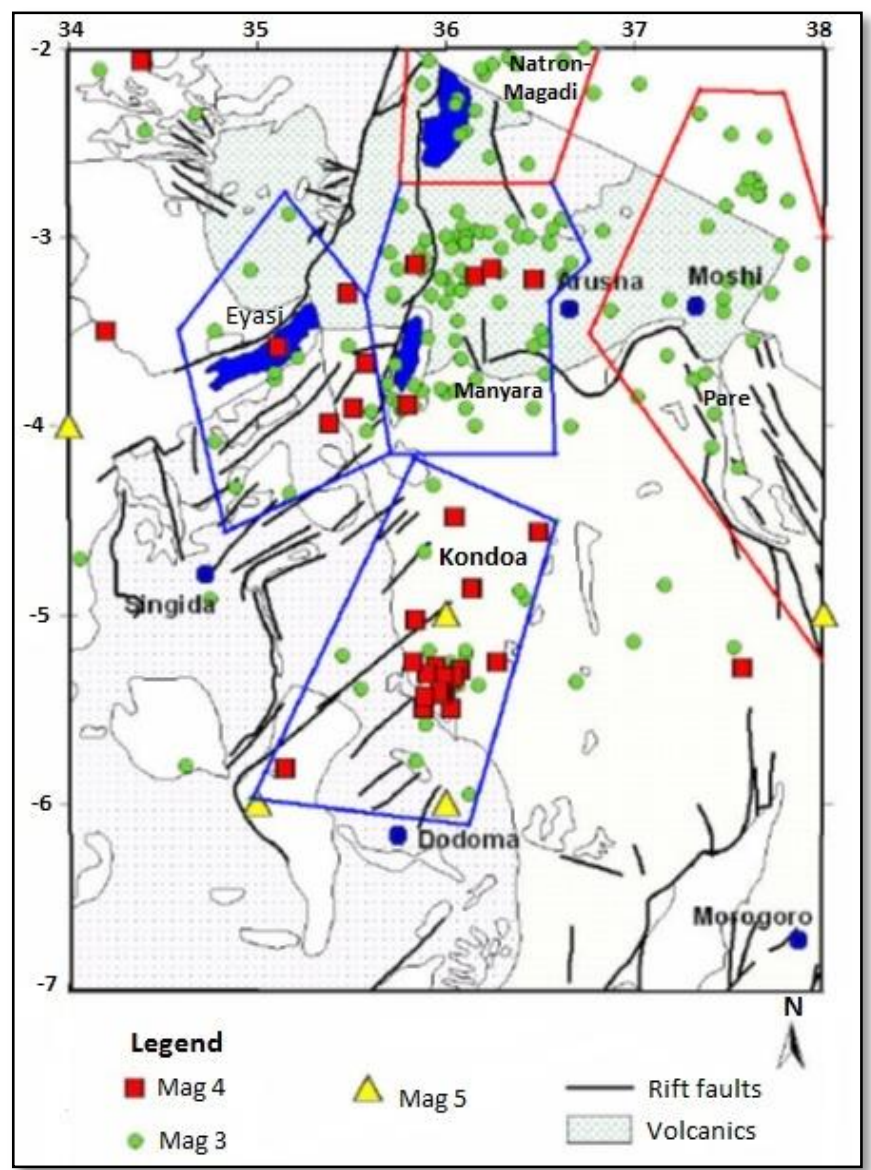

Figure 3: Aerial sources and the distribution of epicentres for the period 1992-1998.

Table 1: One year recurrence relation parameters

\begin{tabular}{lcc}
\hline Seismic zones & a-value & b-value \\
\hline Natron-Magadi & 3.17 & -0.83 \\
Manyara & 2.92 & -0.77 \\
Pare & 2.87 & -0.74 \\
All the five & 3.74 & -0.76 \\
combined & &
\end{tabular}

\section{Ground motion prediction equation}

One of the basic inputs to seismic hazard computations is attenuation relationship, which predicts the expected ground motion at a site at a given distance from an earthquake of a given magnitude. The ground motion is typically characterized by peak ground acceleration or spectral acceleration, or both. Attenuation equations tend to be regional specific and may depend upon site conditions. This study lacked well developed attenuation relation for the EARS region due to lack of strong motion data, and thus, it had to adopt those developed for the western United States rock site conditions (Sadigh et al. 1997). The choice for adopting attenuation relation for western United States was based on the relevance for shallow events in extensional regime similar to EARS region.

\section{Seismic hazard computation}

The Probabilistic Seismic Hazard Assessment (PSHA) combines seismic source zoning, earthquake recurrence and the ground 
motion attenuation to produce hazard curves in terms of levels of ground motion and an associated annual frequency of exceedance. This study performed PSHA for the AICC site using the software EZFRISK (McGuire 1976) by using the areal sources and attenuation equation described above. The maximum amplitude of ground motion expected within a given period of time and corresponding to a chosen probability level is computed. The program yields the annual frequency of exceedance which is equivalent to the reciprocal of the return period.

\section{Results and Discussion}

Results of the PSHA are expressed in terms of uniform hazard response spectra (UHRS) which indicates, for a fixed annual probability of exceedance (return period), the value of the ground motion parameter vs the structural periods. In this study the 5\%-damped UHRS on rock are computed for return periods of 475 years (probability of $10 \%$ in the next $50 \mathrm{yr}$ ), 975 years (probability of $5 \%$ in the next $50 \mathrm{yr}$ ), and of 2,475 years (probability of $2 \%$ in the next $50 \mathrm{yr}$ ). The mean hazard curve for peak horizontal acceleration (PHA) is shown in Figure 4 . The figure shows that the dominant contributor is Manyara source zone. Figure 5 shows mean UHS for return periods of 475 , 975 and 2475 years at the bedrock site. The choice of the curve depends upon the economic life span of the facility at the site. In the case of the AICC buildings, the importance of the structures, e.g., hosting the ICTR and the East African community, the probability of $2 \%$ in the next 50 years equivalent to a return period of 2475 years seems to be adequate. However, this choice is also subject to the impacts of the site effects.

Based on the choice of Uniform Hazard Spectrum above (a return period of 2475 years), accelerogram records from a known earthquake events under similar conditions was selected. For this study, a choice was a shallow earthquake with maximum magnitude, Mw, ranging 6.8-7.5 within the extensional regime at a distance of about $70 \mathrm{~km}$ from the site. Lack of strong motion data within the EARS region led to a selection of the acceleration record of a magnitude, 7.3 Taiwan earthquake in November 1986 (Zeng et al. 1995). Figure 6 shows the matching with the Taiwan event. Based on the fitting, a scaled acceleration record that represents the effect of the seismic source about $70 \mathrm{~km}$ away was produced at the AICC bedrock site. Figure 7 displays the two seismograms.

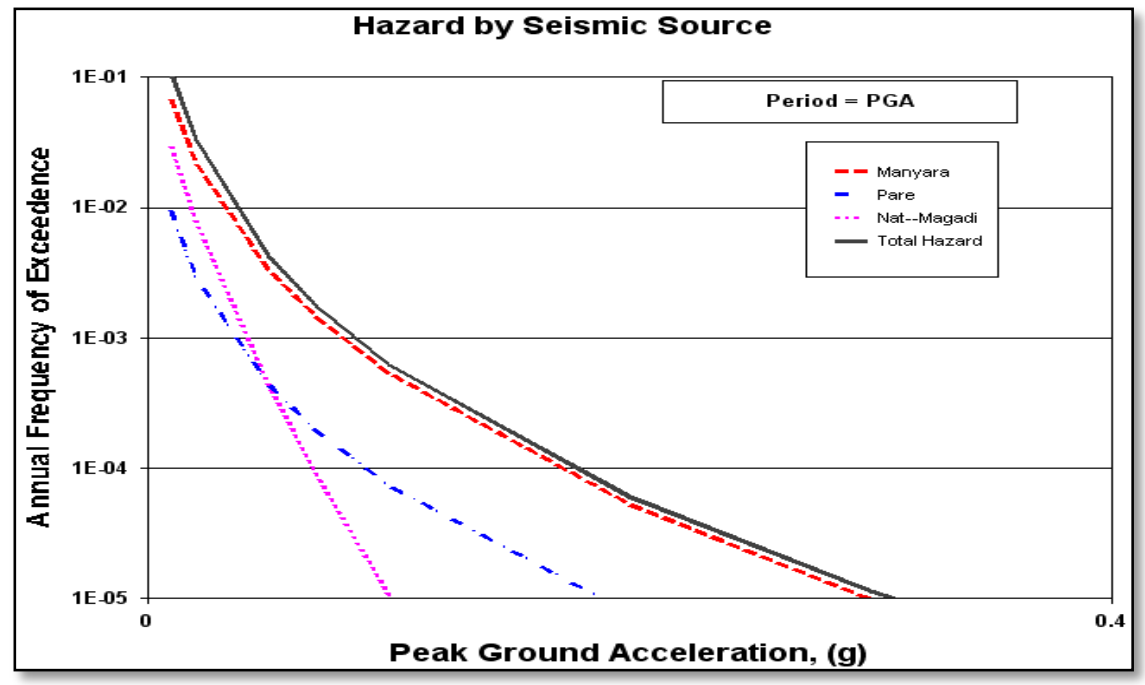

Figure 4: Hazard curves for different sources at the bedrock for AICC site. 
Ferdinand - Probabilistic seismic hazard assessment and site analyses of AICC

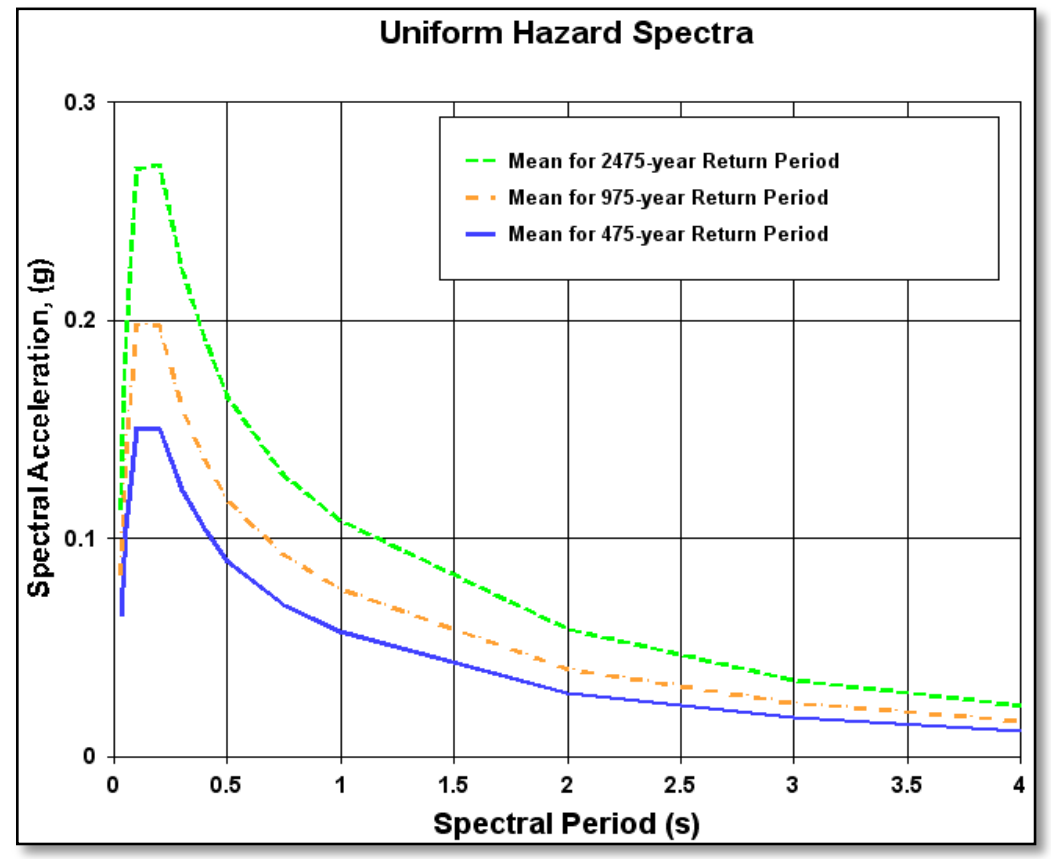

Figure 5: Mean uniform hazard spectra for the return period of 475, 975 and 2475 years.

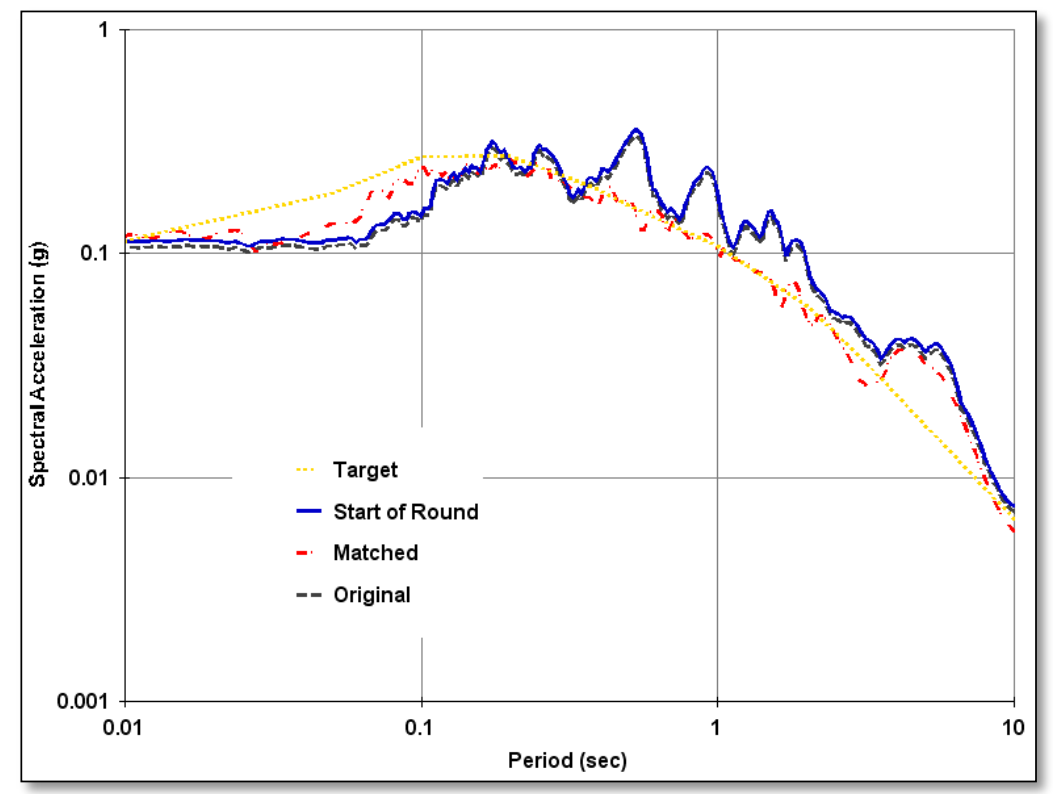

Figure 6: A UHS (2475 year return period) scaled to a Taiwan record of November $1986 \mathrm{M}=$ 7.3 earthquake. 


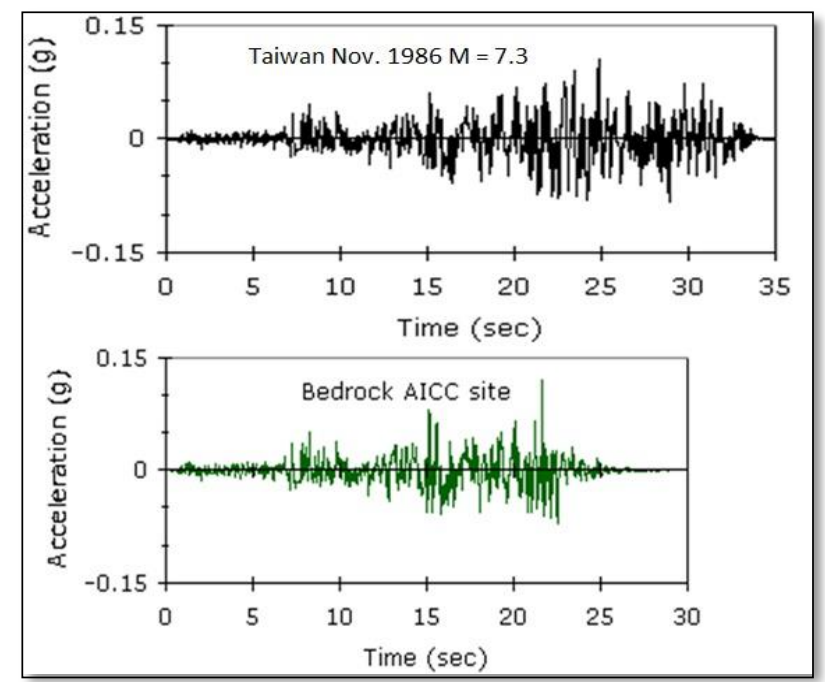

Figure 7: Bedrock acceleration time history for the AICC site and The Taiwan November 1986 $\mathrm{M}=7.3$ earthquake.

\section{Site effect and surface ground motion}

It is known that local geological and soil conditions (site effects) influence the intensity of ground shaking. Local site conditions play an important role in shaping the characteristics of seismic waves. The intensity of ground shaking is often associated with extents of the damage and destructiveness of a site incurs due to the strength of the earthquake. It is therefore important to incorporate some factors of site conditions such as amplification factors into the analysis of seismic risks.

Local site conditions can profoundly influence all the important wave characteristics-amplitude, frequency content and duration of strong ground motion. The extents of their influence depend on the geometry and material properties of the subsurface materials, on-site topography and on the characteristics of the input motion. At most sites, the density and shear wave velocity of the material near the surface are smaller than at greater depths.

Based on the observation of borehole data located within the AICC complex, characteristics of the subsurface materials were obtained (Figure 8). This information together with other borehole drilling information within Arusha City indicate that the basement (metamorphic rock) is overlain by volcanic pile to a depth of about $200 \mathrm{~m}$ (Mwangimba 1992, DDCA 2001, 2002, 2003, 2004, 2005). 
Ferdinand - Probabilistic seismic hazard assessment and site analyses of AICC

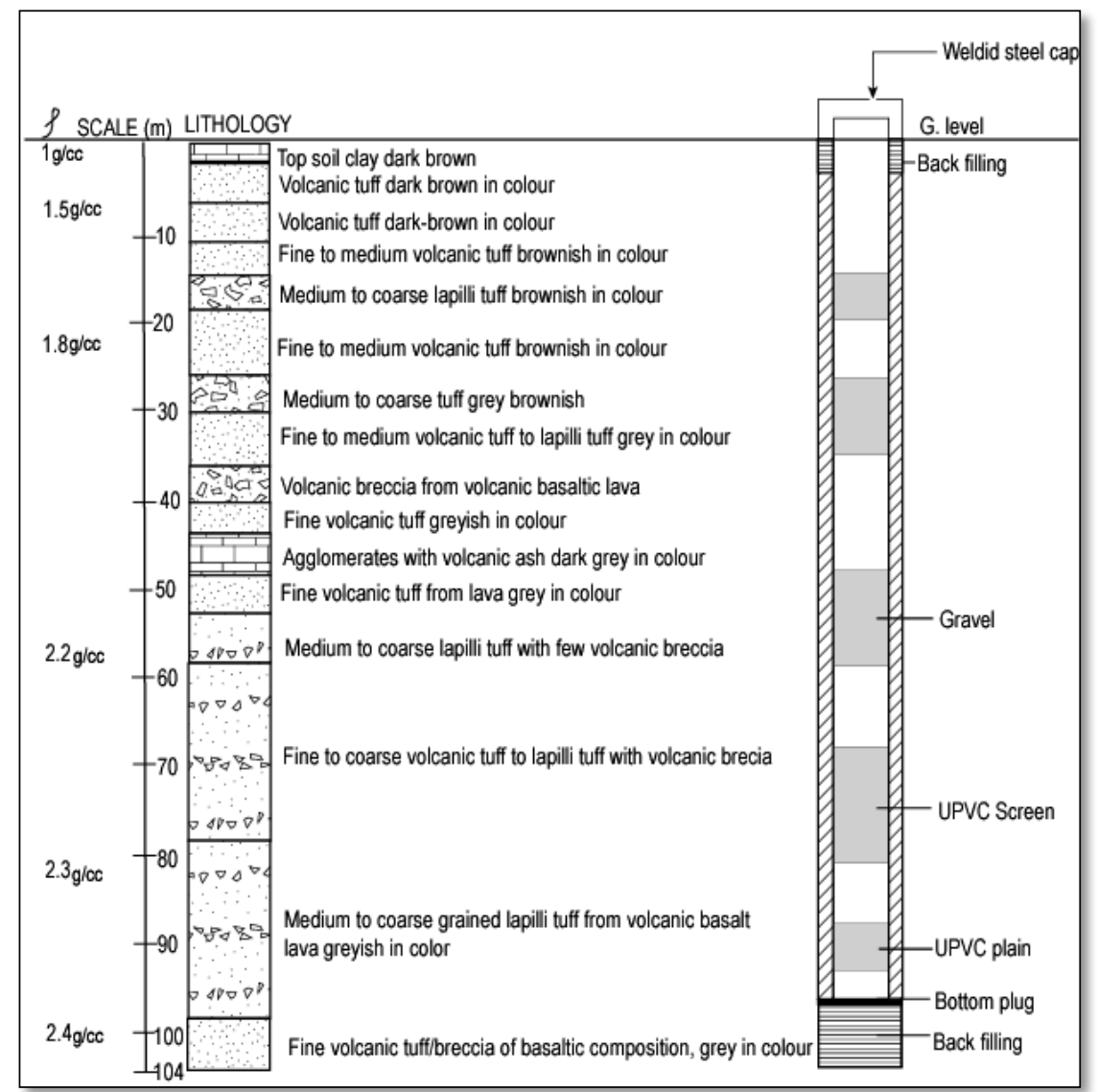

Figure 8: The T-section of AICC borehole information (DDCA 2001).

Based on the input bedrock acceleration time history discussed above motion (accelerogram) and the subsurface material characteristics from the boreholes, the acceleration time history at the site was computed by using a software Shake91 (Idriss and Sun 1992). The computed strong motion is presented by acceleration time history and corresponding response spectra with 5\% damping. Figures 9a, b, c show an acceleration time history, the response spectrum and the site amplification at the surface. From Figure 9c, it can be seen that for all periods below $4 \mathrm{sec}$, the input bedrock signal is being de-amplified leading to a maximum spectral acceleration of $0.06 \mathrm{~g}$ at a period of $1.8 \mathrm{sec}$ (Figure $9 \mathrm{~b}$ ).
Results obtained above (Figure 9a, b, c) are contrary to expectations that sediments could lead to amplification of the bedrock ground motion. Hence, the low surface PGA value, i.e., $0.06 \mathrm{~g}$, obtained at the AICC complex site needs to be explained. Two factors can explain the obtained de-amplification. The first is the period spectrum of the input bedrock PGA (Figure 6). From Figure 6 it can be seen that the maximum amplitudes are at a period range between 0.08 and $2 \mathrm{sec}$. This range falls within the de-amplification zone (Figure 9c), i.e., below $4 \mathrm{sec}$ when the subsurface thickness is taken to be $200 \mathrm{~m}$. As the maximum amplitude signals will be de-amplified, the surface ground motion will be low as well. 


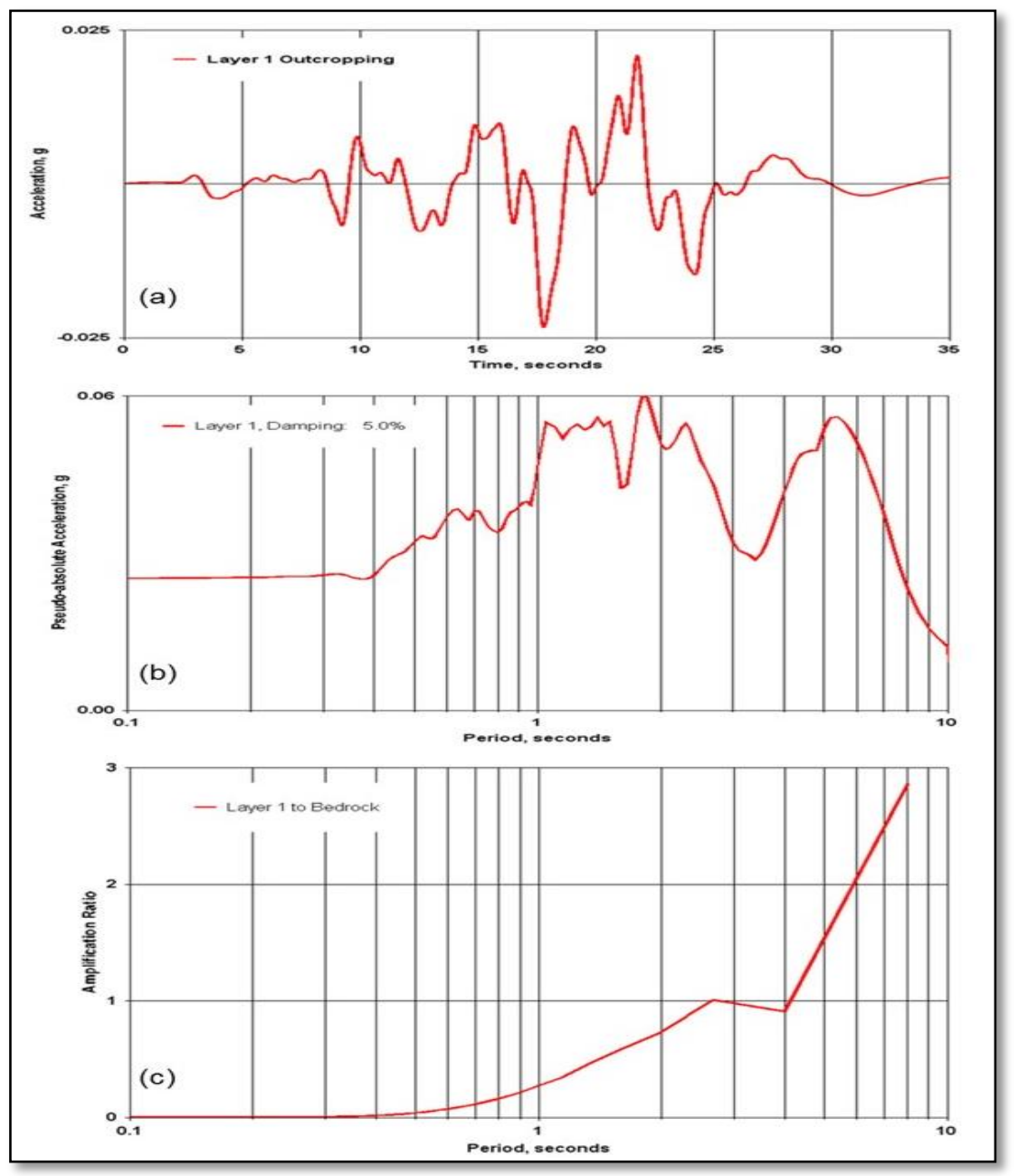

Figure 9: AICC site surface (a) acceleration time history, (b) response spectrum (c) Amplification factor based on a $200 \mathrm{~m}$ thickness of volcanic subsurface.

The second is the thickness and material characteristics of the subsurface layers above the basement at the site. The test has shown that the decrease in the subsurface thickness leads to a decrease in de-amplification and a shift of maximum amplification factor from long period to short period (Figure 10b). For example, the use of only two top layers of a thickness of $18 \mathrm{~m}$ overlying a consolidated layer of basalt lava flow leads to maximum amplification factor of 3.7 at $0.6 \mathrm{sec}$ and a maximum spectral acceleration of $0.45 \mathrm{~g}$ (Figure 10b, c).

The period of $0.6 \mathrm{sec}$ obtained above correspond to a resonance period of a 6 storey building. Majority of the buildings of the AICC complex are 6-7 storey and hence they do match the surface response at the site. This explains the intense of the shaking felt and the minor damage observed at the AICC buildings due to seismic waves of December $5^{\text {th }} 2005$ propagating from Lake Tanganyika earthquake. 


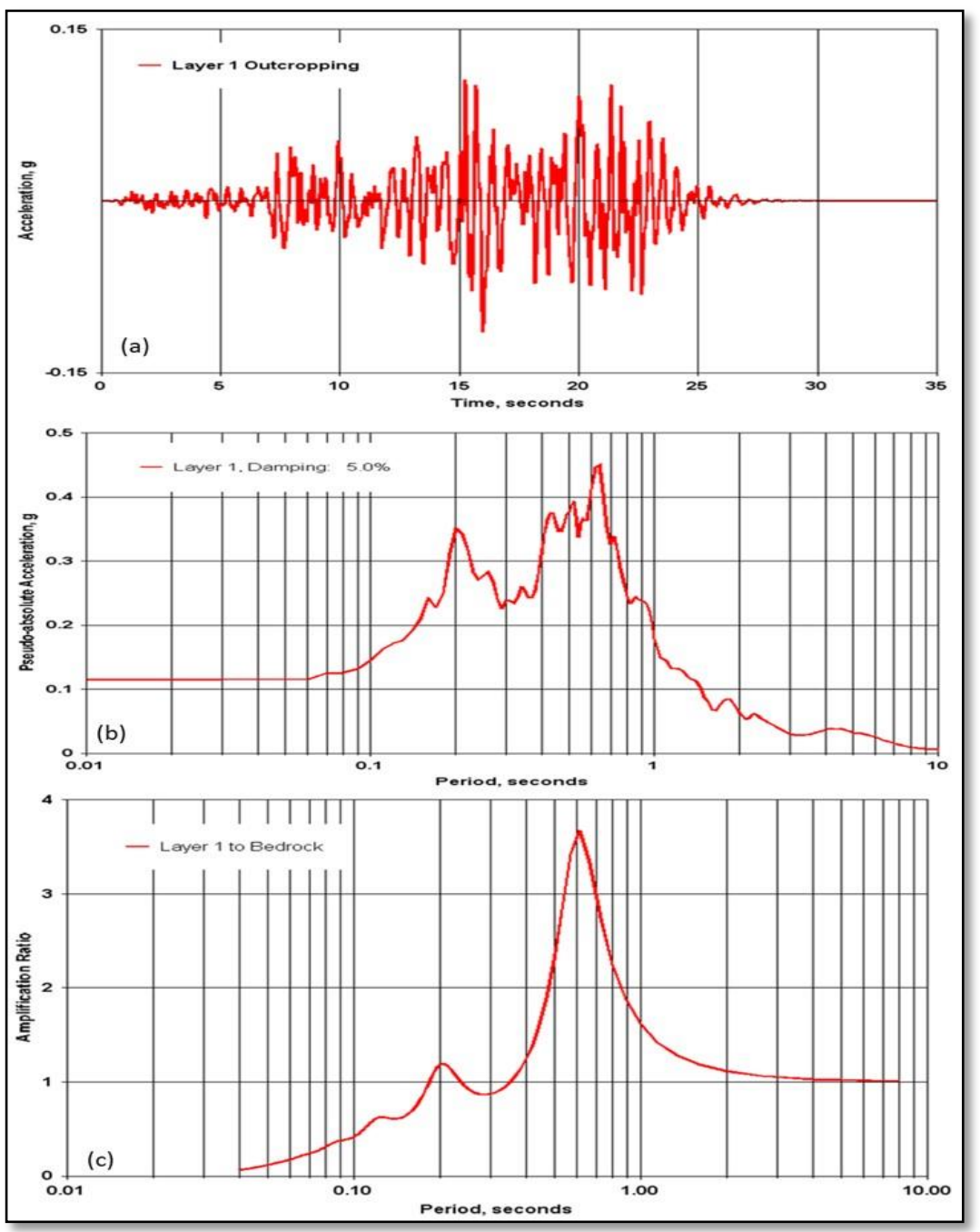

Figure 10: AICC site surface (a) acceleration time history, (b) response spectrum (c) Amplification factor based on a $18 \mathrm{~m}$ thick volcanic subsurface.

\section{Conclusions}

The findings of this study indicated that at a response period of less than $0.3 \mathrm{sec}$, Manyara seismic zone constitutes the dominant seismic hazard. A probabilistic seismic hazard analysis on the bedrock at the AICC site was estimated at peak ground acceleration of $0.27 \mathrm{~g}$ at a return period of 2475 years. Despite the basement at AICC site being overlain by $200 \mathrm{~m}$ of volcanic sediment pile, it is the top $18 \mathrm{~m}$ that constitute unconsolidated sediment overlying consolidated basalt lava flow and which responded during the propagation of seismic waves from the $5^{\text {th }}$ December 2005 Lake Tanganyika earthquake. The observed strong shaking of the AICC building was caused by amplification of seismic waves at the site and the matching of amplified seismic wave period and the natural period of $0.6 \mathrm{sec}$ of the 6-7 storey AICC buildings. The site analysis has revealed a maximum surface spectral 
acceleration of $0.45 \mathrm{~g}$ at 0.6 period for a return period of 2475 years.

\section{References}

Albaric J, Albaric J, Déverchère J, Petit C, Perrot $\mathrm{J}$ and Le Gall B 2009 Crustal rheology and depth distribution of earthquakes: Insights from the central and southern East African Rift System. Tectonophysics 468: 28-41.

Albaric J, Perrot J, Deverchere J, Deschamps A, Le Gall B, Ferdinand RW, Petit C, Tiberi C, Sue C and Songo M 2010 Contrasted seismogenic and rheological behaviours from shallow and deep earthquake sequences in the North Tanzania Divergence, East Africa. $J$. Afr. Earth. Sci. 58: 799-811.

Atakan K, Ojeda A, Meghraoui M, Barka AA, Erdik M and Bodare A 2002 Seismic hazard in Istanbul following the 17 August 1999 Izmit and 12 November 1999 Duzce earthquakes. Bull. Seismol. Soc. Am. 92: 466482.

Bath M 1975 Seismicity of the Tanzania region. Tectonophysics 27: 353-379.

Brazier AR, Nyblade AA and Florentin J 2005 Focal mechanisms and the stress regime in NE and SW Tanzania, East Africa. Geo. Res. Lett. 32(14): L14315.

Cahen L, Snelling N, Delhal J and Vail J 1984 The Geochronology and Evolution of Africa. Clarendon Press.

Calais E, d'Oreye N, Albaric J, Deschamps A, Delvaux D, Déverchere J, Ebinger C, Ferdinand RW, Kervyn F, Macheyeki AS, Oyen A, Perrot J, Saria E, Smets B, Stamps S and Wauthier C 2008 Strain accommodation by slow slip and dyking in a youthful continental rift, East Africa. Nature 456: 783787.

Chávez-García FJ, Sánchez LR and Hatzfeld D 1996 Topographic site effects and HSVR. A comparison between observations and theory. Bull. Seismol. Soc. Am. 86: 1559-1573.

Chorowicz J 2005 The East African Rift System. J. Afr. Earth Sci. 43: 379-410.

Cornell CA 1968 Engineering seismic risk analysis. Bull. Seism. Soc. Am. 58: 15831606.

Daudi G 2007 Investigation of the seismotectonic structure of the eastern branch of the
East African rift system in Tanzania. MSc. thesis, University of Dar es Salaam.

DDCA (Drilling and Dam Construction Agency) 2001 Water-well AICC complex, Arusha. Borehohe completion Report AR 91/2001.

DDCA 2002 Water-well Sakina, Arusha. Borehole completion Report AR 91/2002.

DDCA 2003 Water-well Tengeru, Arusha. Borehohe completion Report AR 471/2003.

DDCA 2004 Water-well Njiro, Arusha. Borehohe completion Report AR 05/2004.

DDCA 2005 Water-well Matevesi Magereza, Arusha. Borehohe completion Report AR $89 / 93$.

DesRoches R, Comerio M, Eberhard M, Mooney W and Rix GJ 2011 Overview of the 2010 Haiti earthquake. Earthquake Spectra 27(1): $1-21$.

Ebinger CJ, Djomani YP, Mbede E, Foster A and Dawson JB 1997 Rifting Archean lithosphere: The Eyasi-Natron-Manyara rift, East Africa. J. Geoph. Soc. Lond. 154: 947-960.

Fairhead JD and Stuart GW 1982 The seismicity of East African rift system and comparison with other continental rifts. Tectonophysics 133: 277-285.

Ferdinand RW, Mulibo GD, Lupogo KP, Nderimo FL, Mtelela K and Mruma A 2017 The Kagera earthquake ( $m w$ 5.9) of September 10, 2016, Tanzania, Technical Report.

Ferdinand RW, Lupogo KP and Mulibo GD 2018 Evaluation of the ground response of the King Mohamed VI stadium Dodoma, Tanzania, Technical Report 2/2018.

Ferdinand RW, Lupogo KP, Mulibo GD and Melchiory S 2020 Seismic hazard and site analyses for the Government City-Mtumba, Dodoma (Phase I). Technical Report 4/2020.

Ferdinand RW, Lupogo KP and Mulibo GD 2021 Seismic hazard and site analyses of the Fire and Rescue Force Residential Site Kikombo, Dodoma, Technical Report 1/2021.

Foster AN, Ebinger C, Mbede E and Rex 1997 Tectonic development of the northern Tanzania sector of the East African Rift System. J. Geol. Soc. 154: 689-700.

Frankel A and Vidale J 1992 A three dimensional simulation of seismic waves in the Santa Clara Valley, California, from a Loma Prieta 
aftershock. Bull. Seismol. Soc. Am. 82: 20452074.

Girdler RW 1991 The Afro-Arabian rift systeman overview. Tectonophysics 197: 139-153.

Idriss IM and Sun JI 1992 Shake91: A computer program for conducting equivalent linear seismic response analysis of horizontally layered soil deposits. User's Guide, Center for Geotechnical Modeling, Department of Civil and Environmental Engineering, University of California.

Iranga MD 1991 An earthquake catalogue for Tanzania 1841-1988. Uppsala University Report 1/91.

Lacave C, Bard PY and Koller MG 1999 Microzonation: techniques and examples. Block 15: Naturgefahren-Erdbebenrisiko. p 23.

Le Gall B, Nonnotte P, Rolet J, Benoit M, Guillou H, Mousseau-Nonnotte M, Albaric J and Deverchère J 2008 Rift propagation at Craton margin. Distribution of faulting and volcanism in the North Tanzania Divergence (East Africa) during Neogene times. Tectonophysics 448: 1-19.

Manya S 2005 Geochemistry and geochronology of the volcanic and plutonic rocks of the Tarime segment of the Musoma-Mara Greenstone Belt, North Tanzania. PhD Thesis, University of Dar es Salaam.

McConnell RB 1972 Geological development of the rift system of Eastern Africa. Geol. Soc. Am. Bull. 83: 2549-2572.

McGuire RK 1976 FORTRAN Computer Program for Seismic Risk Analysis. U.S Geol. Survey Open-File Report No. 76-67.

Msabi MM 2016 Probabilistic seismic hazard analysis for the Northern Tanzania Divergence, $\mathrm{PhD}$ Thesis, University of Dar es Salaam.

Mwangimba EH 1992 Hydrogeological and geoelectrical investigations for the location of borehole site around Tanzania pharmaceutical industries limited, Arusha urban, Arusha. Report.

Mulibo GD and Nyblade AA 2009 The 19941995 Manyara and Kwamtoro earthquake swarms: Variation in the depth extent of seismicity in Northern Tanzania. S. Afr. J. Geol. 112: 387-404.

Mulibo GD 2019 Investigation of macroseismic intensity of the Mw5.9 September 10, 2016 Kagera earthquake: implications for site effect amplification. J. Afr. Earth Sci. 159: 103568.

Nonnotte P, Guillou H, Le Gall B, Benoit M, Cotten J and Scaillet S 2008 New K-Ar age determinations of Kilimanjaro volcano in the North Tanzanian diverging rift, East Africa. $J$. Volcanol. Geotherm. Res. 173: 99-112.

Nyblade AA and Robinson SW 1994 The African superwell. Geophys. Res. Lett. 21: 765-768.

Nyblade AA, Birt C, Langston CA, Owen TJ and Last RJ 1996 Seismic experiment reveals rifting of craton in Tanzania. Eos Trans. AGU 77: 517-521.

Pitilakis K 2004 Site effects. In: Recent advances in earthquake geotechnical engineering and microzonation. pp. 139-197, Springer, Dordrecht.

Quennell AM, McKinley ACM and Aiken WG 1956 Summary of the geology of Tanganyika: introduction and stratigraphy. Tanganyika Geol. Surv. Mem. 1 (Pt. 1) 264 pp.

Ring U 2014 The East African rift system. Austrian J. Earth Sci. 107(1): 132-146.

Sadigh K, Chang CY, Egan JA, Makdisi F and Youngs RR 1997 Attenuation relationship for shallow crustal earthquakes based on California strong motion data. Seismol. Res. Let. 68: 180-189.

Schlüter T 1997 Geology of East Africa. Beiträge zur Regionalen Geologie der Erde. Ge ISBN 978-3-443-11027-7.

Shearer PM and Orcutt JA 1987 Surface and near-surface effects on seismic waves theory and borehole seismometer results. Bull. Seismol. Soc. Am. 77: 1168-1196.

Zeng TY, Yao ZX and Liu PC 1995 The 14 November 1986 Taiwan earthquake-an event with isotropic component. Phys. Earth Planet. Inter. 91(4): 285-298. 